\title{
Quality assurance and e-learning: blue skies and pragmatism
}

\author{
Ron Oliver*
}

Edith Cowan University, Australia

This paper considers the role of quality assurance in e-learning; reflecting on the conditions necessary for successful e-learning. It reviews some of the current international work on quality assurance in this area and goes on to consider the ways in which the quality of a process or activity can be assessed - focusing on the use of benchmarking and specification of standards.

\section{Introduction}

There is still a high degree of scepticism and concern being expressed by many that the use of information and communications technology (ICT) in education remains an unproven experiment, despite the huge investments in technology and infrastructure and the high levels of interest that remains among many educators, administrators and policy-makers (for example, Cuban, 2003; Oppenheimer, 2003). The principal concern expressed by many critics of ICT in education is the lack of empirical evidence for learning enhancement, and ICT is often seen to do more harm than the good it generates as a consequence of the overheads and associated costs (for example, Oppenheimer, 2003). In higher education, where ICT in teaching and learning is probably more prominent than in any other sector, this degree of scepticism appears just as strong (for example, Romizowski, 2005). Large-scale moves to use technology to support teaching and learning have been seen to be premised on poor assumptions and inaccurate perceptions of public response.

Many projects such as the UK eUniversity, NYU Online, Scottish Knowledge, Universitas 21 and Global University Alliance, which all developed around e-learning applications, have failed to realise their aims and goals, leading many to question the quality and capabilities of this form of educational delivery (Garrett, 2004). Like all forms of education, there are both good and bad examples in practical settings. The questions many people are looking to answer are: what are the necessary conditions

\footnotetext{
*Faculty of Communications and Creative Industries, Edith Cowan University, 2 Bradford St, Mt Lawley, 6050, Western Australia. Email: r.oliver@ecu.edu.au
} 
for successful e-learning, and can these conditions guarantee that e-learning will be successful? Many of these questions have become more important in the current era where accountability is a key concern in the higher education sector.

\section{The quality agenda}

There is currently a quality agenda running among educational institutions worldwide, and within higher education in particular. It is a prominent and mainstream activity that seeks to ensure that there is accountability in the ways in which institutions go about their daily work. The notion of quality in the delivery of education is generally contextualised within three possible definitions: quality as value for money, quality as fit for purpose of the institution or quality as transforming (Biggs, 2001).

Biggs (2001) argues that the quality agenda that confronts many in higher education today involves mainly quality assurance processes based on public accountability. For example:

- accountability to a funding body, for example, the Government;

- a desire to improve outcomes;

- the prospect of new opportunities;

- being able to sustain programmes and activities; and

- an ability to demonstrate achievement against stated goals.

Biggs calls such quality assurance processes retrospective activities, because they look back to see what has been done rather than looking forward (prospective) to see what can be done to transform and change educational processes to improve the service delivery.

The movement, while worldwide, appears to have grown mainly from activities in the United Kingdom where quality assurance processes have been in place for some time. The Quality Assurance Agency for Higher Education (QAAHE) in the United Kingdom describes the aims of quality assurance of teaching and learning in higher education as being to:

- contribute, in conjunction with other mechanisms, to the promotion of high quality and standards in teaching and learning;

- provide students, employers and others with reliable and consistent information about quality and standards at each higher education institution (HEI);

- ensure that HE programmes are identified where quality or standards are unsatisfactory, as a basis for ensuring rapid action to improve them; provide one means of securing accountability for the use of public funds received by HEIs (QAAHE, 2001, p. 2).

There is a similar high degree of quality activity in higher education in Australia as a consequence of the actions of the Australian University Quality Agency. This agency, acting under the authority of the Commonwealth Government, conducts regular quality audits and provides public reports on the quality assurance arrangements of self-accrediting higher education institutions in Australia. This quality audit process 
encompasses all aspects of institutions' activities including, teaching and learning, research and management, including those activities that involve offshore elements.

There is an abundance of literature that describes quality in teaching and learning in higher education (for example, Ramsden, 1992; Laurillard, 1993). Quality assurance in this setting is achieved primarily through detailed examinations of the broad aims and goals across such diverse aspects of the teaching programmes as the curriculum offered, its implementation, assessment processes and student learning outcomes. Questions that are fundamental to underpinning an examination of an organisation's teaching and learning practices and outcomes include the following (University of Tasmania, 2000):

- What quality assurance policies and practices does the institutions have in place or in the process of development to assure the quality of its teaching and learning performance?

- How effective and how fully deployed are these?

- What processes does the institution have to evaluate and monitor the quality of its outcomes?

- What quality-related indicators does the institution use and why?

- What are the institution's priorities for improvement?

- What quality initiatives has the institutions undertaken (since the last review) and what evidence of improved performance is there?

As technology has become increasingly applied in education, its use in the delivery of teaching and learning has led many to distinguish this as a discrete educational form, called e-learning (for example, Stella \& Gnanam, 2004). As a teaching and learning activity, e-learning has now been caught up in the quality agenda. Many national bodies and organisations have now developed principles, guidelines and benchmarks to describe quality in the use of technologies to support flexible learning. For example, the Institute for Higher Education Policy (2000) in the USA describes a series of benchmarks that are argued as essential to ensuring excellence in Internet-based distance learning. Likewise, in the United Kingdom the Quality Assurance Agency (QAA) describes a code of practice for the assurance of academic quality and standards in the provision of flexible and distributed learning, including e-learning (QAA, 2004).

E-learning is a form of educational delivery that has become quite prominent in universities worldwide and an activity that, to all intents and purposes, can now be considered mainstream. Despite its uptake, however, as with conventional teaching in higher education, e-learning is often done well and poorly in different locations within the same university. One of the main problems with e-learning is that its practice has evolved from conventional teaching and learning, and its application tends to involve variations and copies of face-to-face teaching rather than practices developed from a 'green-field' approach (for example, Collis \& Moonen, 2001). Contemporary research is continuing to explore e-learning as a discrete activity and to distil factors that influence its success and achievements. There is still uncertainty and doubt among many as to what actually constitutes a quality e-learning approach, and it is this question that this paper seeks to explore. 


\section{Quality and e-learning}

One of the problems facing those who seek to describe quality in e-learning is understanding precisely what constitutes e-learning. E-learning occurs in a wide range of teaching activities where technology of one form or another is involved. Technology necessarily underpins the administrative functions of most universities and higher education institutions and, for many, the lines between the administration, and the conduct, of teaching can be blurred. E-learning takes many forms, and common instantiations in e-learning delivery and approaches include:

- flexible learning, technology supports for learning any time, anywhere;

- blended learning, varying mixes of technology with conventional learning usually in conventional settings; and

- online learning, where technology provides the means for the implementation and delivery of learning programmes totally distinct from face-to-face teaching (for example, Fresen, 2005).

Within this diverse and broad range of activities, we are now seeing increased levels of awareness and concern for the quality of the activities that result. There is a heightened level of interest in being able to monitor and review performance and to demonstrate successful outcomes. In catering for the diversity, most exercises in quality assurance steer towards the activities with the highest levels of technology use and dependence; for example, distance education and online learning (for example, Institute for Higher Education Policy, 2000; QAA, 2004). Once parameters have been set for excellence and best practice in this form, the variations that exist among e-learning examples that come from a blended learning or flexible delivery form can still be adequately accommodated.

The literature that describes successful teaching and learning in online settings typically draws from research that has focused on discrete aspects of e-learning in particular settings. For example, a research project might explore levels of learner participation in an online discussion. The myriad of research clearly shows that there is a large range of activities and outcomes upon which the successful application of elearning processes depends. In the big picture, these include such aspects as:

- the scope and nature of the learning materials;

- appropriate selection of the learning design;

- the levels of learner engagement;

- extent of community development within virtual settings;

- scope and level of flexibility of learning;

- enhanced learning;

- reusability of the resources;

- the accessibility of the resources; and

- the level of uptake of e-learning among staff (for example, Khan, 1997; Kearsley, 2005).

In an era of increased accountability, it is important for stakeholders in educational organisations to be able to demonstrate that their approaches to e-learning are sound 
and effective. They need to be able to demonstrate that they are carry out e-learning in a way that is efficient and productive, and they must be able to demonstrate quality in the curriculum, the delivery and their teaching and learning approaches.

\section{Assessing quality}

There are usually two main ways by which the quality of a process or activity can be assessed, through benchmarking or by the specification of standards. Benchmarking compares the performance and outcomes in one setting against that achieved by selected others operating in a similar sphere, a process of relativity; whereas the use of standards uses criterion-related references to judge performance. Benchmarking enables an organisation to see how its performance compares against others. It can demonstrate what is good or poor practice through comparisons against established best practice. It is a process commonly used in industry in which businesses use known leaders as models and targets. The process involves comparing local practices against known best practice to determine where there is a need to improve. In industry, benchmarking systematically uses quality assurance processes to identify examples of excellence and best practice, and then uses these examples as the standard of comparison (for example, Achtemeir \& Simpson, 2005).

Benchmarking is a difficult process to apply in most university settings. McKinnon et al. argue that:

No area of university life [learning and teaching] is more difficult to benchmark. It is characteristic of universities that the courses and the approach to teaching them are not standard. Courses, even professional courses leading to registration, are rarely, readily or directly comparable. There will always be diversity. (2000, p. 69)

E-learning is one activity in university settings where benchmarking processes might be employed to ascertain quality. E-learning comprises discrete and distinct teaching and learning elements that can be isolated and identified for benchmarking purposes. There currently exist a number of standards and guidelines that have been developed to aid this process (for example, Institute for Higher Education Policy, 2000; Learning Object Metadata (LOM), 2002; Learning Technology Standards Committee (LTSC), 2002; QAA, 2004). At the same time, there has been considerable research and development in e-learning and many reports have resulted that showcase examples of best practice and that can be used as potential benchmarks against which comparisons can be drawn. The difficult aspect in this process is perhaps the steps associated with making judgements concerning the choice of best practice examples, which might be used as a benchmark example.

A number of researchers have attempted to provide frameworks that can be used to provide overarching models to describe the critical elements of learning settings that can be used to contextualise the factors influencing effective outcomes (for example, Sims et al., 2002). Typically the frameworks distinguish four discrete elements;

- The curriculum, that which is to be learned. A strong curriculum has relevance to the student and the workplace. It has currency and reflects best practice. 
- The learning design, the planned learning environment. An effective learning design provides the forms of learner engagement required to assist the learner to interact with that which has to be learned in meaningful ways.

- The learning resources, the course content. Strong course content is accessible and current. It provides multiple perspectives and conceptual underpinning.

- The delivery processes, supports and scaffolds for learning. A strong delivery process supports the learners, provides contexts for communication and collaboration.

Within these four elements, there are examples of best practice that apply to teaching and learning in general, and examples that could be considered unique to e-learning. Since e-learning is primarily a descriptor of the medium of instruction, descriptions of best practice would tend to apply mainly to instantiations of a curriculum and course, more than the design of the course itself. From the earlier list, this leaves learning designs, learning resources and delivery processes as the elements of elearning that could form the basis of any benchmarking activity.

\section{Learning designs for quality e-learning}

The term learning design (see for example Britain, 2004) describes the deliberate learning activities and processes that a teacher or instructional designer plans into a learning environment to provide the cognitive engagement a learner is deemed to require in a learning experience, to bring about the required conceptual change associated with the planned learning outcomes (Kalantzis \& Cope, 2004). Learning designs may be at the level of a whole subject, subject component or learning resource (for example, Hedberg et al., 2002). Boud and Prosser (2002) argue that high-quality learning activities must demonstrate four principles:

- Engagement of learners.

- Acknowledgement of context.

- Challenge for learners.

- The involvement of practice.

E-learning settings across all sectors of education have long been criticised for their limited and shallow learning designs (for example, Mioduser et al., 1999). Typical online courses are usually comprised of comprehensive electronic resource sets and information with little intentional instructional design aimed at supporting meaningful learning. The most common forms of learning design involve students reading screen-based texts and answering questions designed to promote engagement.

In a large study of technology-based learning examples undertaken in Australia in 2003, a number of different learning designs supporting quality learning experiences were identified and described and exemplars included into an online database (Australian University Standards Committee, 2003). The database was designed with supporting information and resources to facilitate the implementation of the learning designs by teachers in areas beyond their immediate contexts (Figure 1). Within this database, quality learning designs are all characterised as 


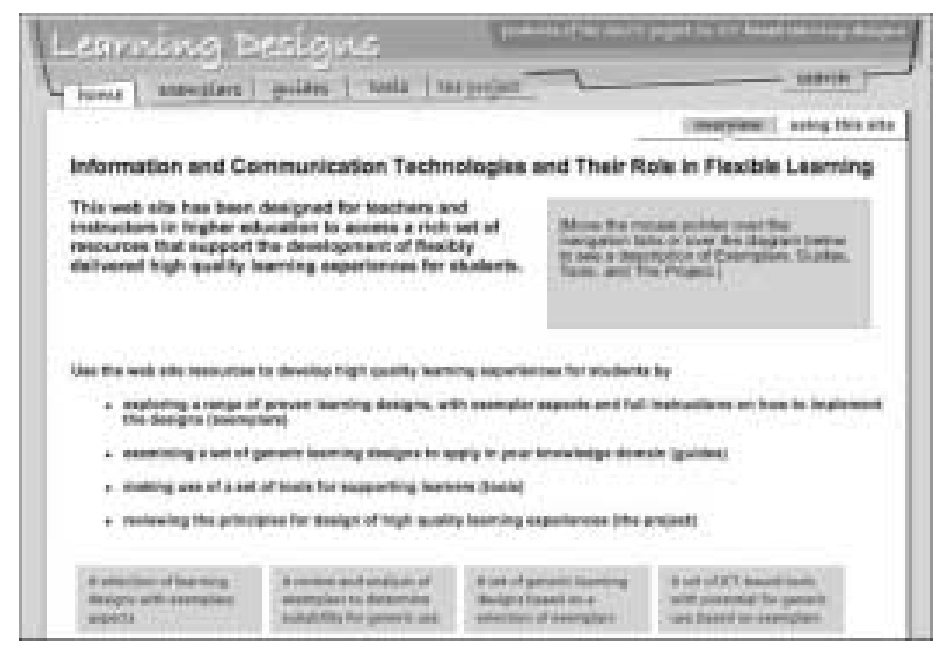

Figure 1. ICTs and their role in flexible learning. A repository of high-quality learning designs for e-learning (http://www.learningdesigns.uow.edu.au) (Australian University Teaching Committee, 2003)

being forms of problem types derived from the work of Jonassen (2000). The learning designs are based on problem solutions of a rule-based, an incidentbased, a strategy-based or a role-based form (Oliver et al., 2002).

In choosing a benchmark of best practice for a learning design in e-learning, it is important to ensure that there is a deliberate form of learning experience supported and that the learning experience is well matched to the intended learning outcomes. Given the wide variation in learning outcomes being sought, subjects being covered and learning levels being considered, benchmarks for e-learning designs necessarily require considerable judgement and discernment.

\section{Learning resources for quality e-learning}

The learning resources in e-learning settings provide the content and course materials that underpin the conceptual change in the planned learning outcomes. In most elearning settings there are substantial amounts of course material provided for learners, and the factors of the materials that influence quality are in most instances the same as those that influence the quality of conventional resource sets. For example:

- How well the resources support the planned learning.

- The scope of the resources.

- The currency of the resources.

- Appropriateness of media usage.

- The relevance of the resources.

A growing awareness has emerged of the duplication and proliferation of online resources, and much has been written on the topic of reusability as both a design 
and development strategy for online learning materials and as a general approach to the use of digital resources for teaching and learning (for example, Downes, 2000). The reusability of learning resources offers many advantages to all stakeholders in the learning process and is now considered an important factor in any elearning process. There are many benefits to be gained from such stakeholders, such as:

- The administrative and financial agents who can benefit from the potential costs savings associated with reusing and sharing learning resources.

- The policy-makers who are interested in the legal and ethical implications of copyright and intellectual property about digital resources.

- The instructional designers who can gain from design strategies that facilitate and support sharing and reuse.

- The resource developers who can gain efficiencies and economies of scale from development strategies that ensure interoperability and a capability for use of resources beyond the context for which they are designed (for example, Downes, 2000; Shepherd, 2000).

The term learning object is commonly used today when referring to reusable digital learning resources. Many writers, however, find this term distracting and misleading, and are very cautious in its use (for example, Friesen, 2003). The IEEE Learning Technology Standards Committee (LTSC, 2005) describes a learning object as any entity digital or non-digital that can be used for learning education or training. Much of the current work with learning objects is seeking to provide systems and processes to enable teachers, when creating e-learning environments, to be able to discover and locate online resources that can be seamlessly incorporated into their learning settings.

There has been a huge amount of work undertaken by a number of large organisations and groups to facilitate the reusability and interoperability of digital learning resources; for example, the work of the IMS Global Learning Consortium, Advanced Distributed Learning, and IEEE. This work appears to be removing many of the barriers that have previously limited reuse of learning resources. The work being done to develop the Sharable Content Object Reference Model (SCORM) is a strong case in point. SCORM has been developed by the Advanced Distributed Learning Initiative and provides a design and development model for learning resources that strongly supports reusability and interoperability (Advanced Distributed Learning Initiative, 2004). Discovery of stored resources is facilitated by the use of learning object metadata and shared vocabularies to provide descriptors for resources that can be used in the discovery process (for example, LOM, 2002; LTSC, 2005).

There are a growing number of repositories and databases of digital resources built and developed to foster the reuse of learning resources. Popular virtual learning environments such as WebCT, Blackboard and Desire2Learn all support and encourage the development and use of resources that have been designed with reusability in mind, and these tools, plus many others, now provide functionality for the storage 


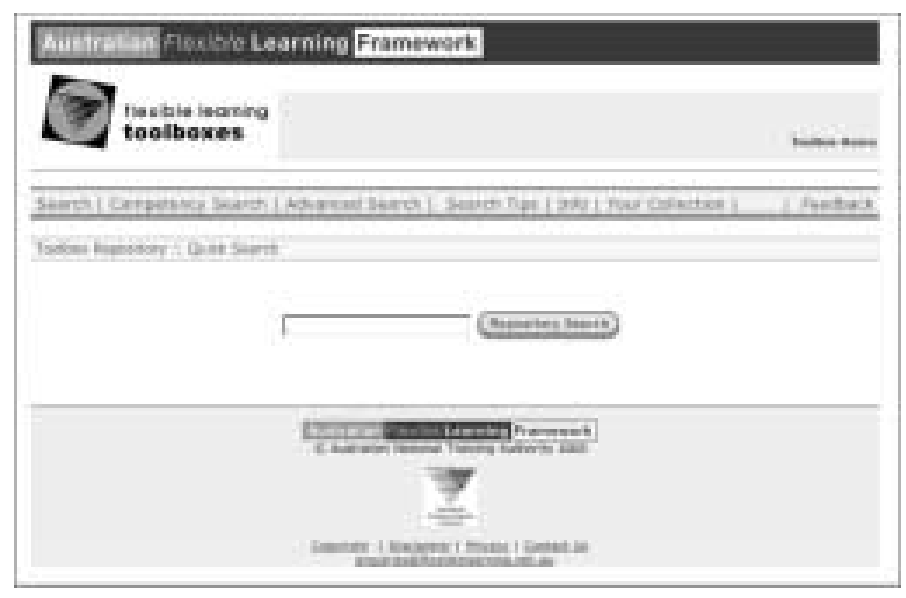

Figure 2. The Flexible Learning Toolbox digital repository facilitating the discovery and reuse of learning resources (http://flexiblelearning.net.au/search.asp) (Flexible Learning Advisory Group, 2003)

and retrieval of digital resources. Figure 2 shows the Flexible Learning Toolbox digital repository developed as part of an Australian project involving the large-scale development of e-learning resources for use in the vocational and educational sector. The project explored the design and development strategies needed to support the storage, discover and reuse of digital resources designed for specific settings. Many factors were found to influence the reusability of the resources and guidelines were prepared to guide developers and designers seeking these outcomes (Brownfield \& Oliver, 2003).

There are many factors that contribute to the quality of learning resources and among these a significant number are particular to the digital resources that support e-learning. In developing benchmarks for the purpose of ascertaining quality, it is important to ensure that the examples of best practice that are selected as the basis for the benchmarking process are reflective of the contemporary thinking in this area, especially in relation to reusability and interoperability; factors that many universities have yet to adequately deal with.

\section{Supporting quality e-learning}

The effectiveness of a student's e-learning experience depends not only on learning design and learning resources, but also on the manner in which it is delivered and supported. Learning supports describe the measures and means by which learners interact with systems, peers, mentors and teachers in the learning process. Previously, many thought that well-designed e-learning settings would facilitate independent learning with little or no need for interaction with others, in the same vein as distance education modes had traditionally operated. Experience and research has shown that this is not the case. Students in e-learning settings can derive many 
benefits from well supported learning strategies. They frequently strive for the company of their co-learners and often they seek the support and involvement of a tutor to facilitate and guide their learning experiences. A number of writers argue quite strongly that effective learning settings must involve such forms of learner support as mentoring, modelling, coaching and scaffolding (for example, Dennen, 2002). Providing these supports in e-learning, settings can be achieved through a variety of means and at many different levels, and has been the focus of considerable research in recent years (for example, Salmon, 2002).

The provision of support mechanisms for students in e-learning settings contributes to the learning experience in a number of ways:

- It enables learners to establish a sense of belonging and involvement, a sense of community, which encourages and motivates participation;

- Supports can scaffold learning and help students to undertake and complete activities and tasks they might not be able to do on their own;

- Learning supports in the form of communications and discussions provide opportunities for higher-order thinking and conceptual development, often not evident in independent learning settings (for example, Brook \& Oliver, 2004).

The process of benchmarking best practice in the provision of support for e-learning can be a movable feast. Research is continually discovering and demonstrating innovative technology-facilitated strategies and tools that provide learning opportunities and enhancements over conventional forms. Figure 3 showcases MarkUp, an innovative tool that assists learners to make meaning from readings. Learners are able to post their thoughts and reflections, using 'sticky notes', into an online document and to view and share the postings made by others. When use of this tool was investigated with learners, the act of marking-up readings in a deliberate fashion and

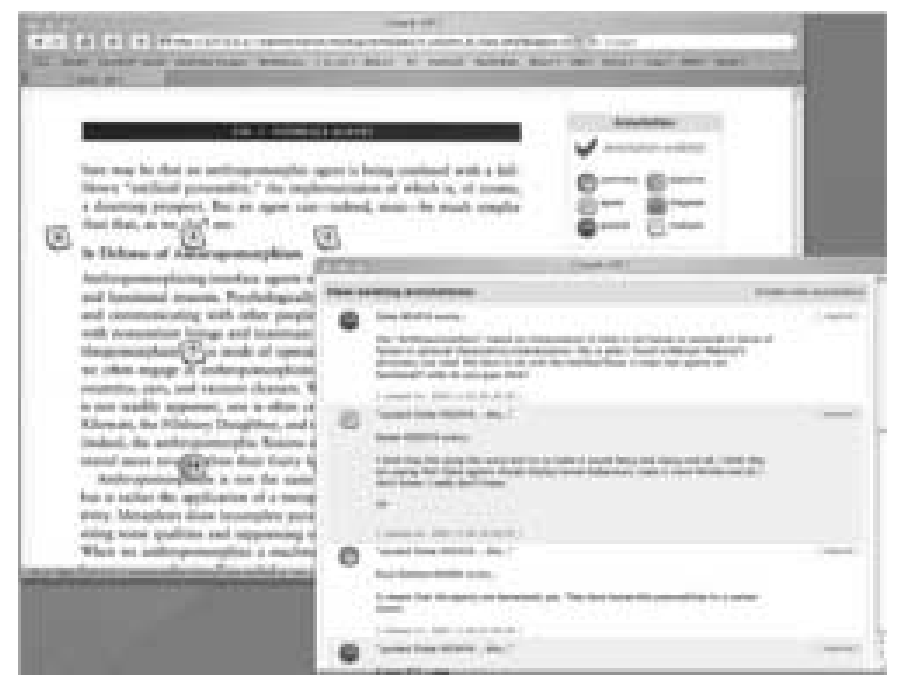

Figure 3. MarkUp, an online tool facilitating reading comprehension and shared viewpoints 
reviewing others' comments was found to provide strong supports for reading comprehension and the development of learners' metacognitive skills (McMahon \& Oliver, 2003).

There are now many strategies and tools that can be used to support e-learning. All virtual learning environments and courseware management systems provide facilities such as discussion boards, chatrooms and groupware as a matter of course. The quality issue revolves not around whether these tools are available, but the strategies and means teachers employ to make effective use of them in the learning setting. Best practice in e-learning and all forms of learning involves high levels of deliberate and planned learner support through these means.

\section{Concluding remarks}

The presented descriptions of examples of strong practice in e-learning provide some avenues for those looking to use benchmarking as a means of quality assurance. One of the difficulties benchmarking poses for quality assuring learning in higher education (for example, Achtemeir \& Simpson, 2005) is the process of describing best practice in a way that supports the necessary comparative process. There have been a number of recent attempts to describe and state standards as an alternative means. Standards provide levels of achievement of a benchmark that can be qualitatively or quantitatively measured.

The use of standards provides a means for the quality and scope of services to be documented and for the provision of such to be monitored against stated objectives. While standards have been applied for many years to business services, it is only recently that they have been considered in education and training. McKinnon et al. (2000) provide a detailed discussion of standards as a means for quality assuring teaching and learning in higher education, and from this work we have developed a framework that we think can be used as a starting point for planning standards to assist the benchmarking process in quality assuring e-learning (Figure 4).

The teaching and learning framework described in Figure 4 is broad and includes many features that do not specifically relate to e-learning but describe issues needed to assure teaching and learning in general. In the framework, e-learning is important in both the inputs and processes areas, where the quality of the materials are considered, as well as the provision of the learning experiences and the assessment of learning. In this paper, a number of quality issues have been discussed in relation to best-practice in e-learning, and these issues have been tied to a discussion of quality assurance processes involving benchmarking against these best practices. As more and more universities seek to use e-learning as a mode of delivery for their units and courses, and as more and more they are being held accountable for the quality of the services they provide, the need grows for accepted standards and benchmarks against which performance can be judged.

This paper has discussed and described some of the main factors associated with quality performance in the provision of e-learning services in higher education and 


\begin{tabular}{|c|c|c|}
\hline & Teaching & Leaming \\
\hline $\begin{array}{l}\text { Inputs } \\
\text { clements and attributes } \\
\text { which describe pre- } \\
\text { conditions for successful } \\
\text { leaching and lesring }\end{array}$ & $\begin{array}{l}\text { - course establishment and course } \\
\text { review processes } \\
\text { - curnculum specifications } \\
\text { - course materials and resources } \\
\text { - teacher qualfications and currency } \\
\text { - strategic plan for teaching and } \\
\text { leaming } \\
\text { - facilities and resources for teaching } \\
\text { and learning }\end{array}$ & $\begin{array}{l}\text { - student selection and entry into } \\
\text { courses } \\
\text { - students' progression through } \\
\text { courses }\end{array}$ \\
\hline $\begin{array}{l}\text { Processes } \\
\text { elements and attributes } \\
\text { which describe on-going } \\
\text { condtions for successful } \\
\text { teaching and learning }\end{array}$ & \multicolumn{2}{|c|}{$\begin{array}{l}\text { - provision of appropriate learning experiences } \\
\text { - work, conmunity and professional engagement } \\
\text { - assessment procedures } \\
\text { - student support }\end{array}$} \\
\hline $\begin{array}{l}\text { Outputs } \\
\text { elements and atinbutes } \\
\text { which describe post. } \\
\text { conditions for successtul } \\
\text { leaching and learing }\end{array}$ & $\begin{array}{l}\text { - continuous improvement in } \\
\text { teaching processes } \\
\text { - refiective practice and sngoing } \\
\text { commitment to continuous } \\
\text { improvement in teaching } \\
\text { processes }\end{array}$ & $\begin{array}{l}\text { - graduates are employable in } \\
\text { various ways } \\
\text { - graduates can demonstrate } \\
\text { outcomes } \\
\text { - course satisfaction and attitudes }\end{array}$ \\
\hline
\end{tabular}

Figure 4. A framework describing quality teaching and learning (Oliver et al., 2006)

has provided examples of current practice that exemplify these. The paper has highlighted difficulties associated with quality assuring e-learning given the depth and breadth of the activity, but has demonstrated that there are guiding principles that can be used and there are examples of institutions seeking to explore benchmarking and standards as quality assurance processes for e-learning activities.

As institutions across all sectors of education proceed to mainstream e-learning as an alternative form of programme delivery, the need for objective measures of quality will grow. E-learning is an activity that has many costs and makes many demands. It will be important to be able to satisfy stakeholders that the activity is 
providing the maximum possible return on investment and that further investment is warranted. To do this, there is a need to discover and document best practice models that institutions can use to grow their capabilities and performances, and also that benchmarks against quality can be demonstrated.

\section{References}

Achtemeir, S. \& Simpson, R. (2005) Practical considerations when using benchmarking for accountability in higher education, Innovative Higher Education, 30(2), 117-128.

Advanced Distributed Learning Initiative (2004) Sharable content object reference model, version 2004. Available online at: http://www.adlnet.org/technologies/SCORM/index.cfm (accessed 25 May 2005).

Australian University Teaching Commission (2003) ICTs and their role in flexible learning. Available online at: http://learningdesigns.uow.edu.au (accessed 31 August 2005).

Biggs, J. (2001) The reflective institution: assuring and enhancing the quality of teaching and learning, Higher Education, 41, 221-238.

Boud. D. \& Prosser, M. (2002) Key principles for high quality student learning in higher education: a framework for evaluation, Educational Media International, 39(3), 237-245.

Britain, S. (2004) A review of learning design: concept, specification and tools. Available online at: www.jisc.ac.uk/uploaded_documents/ACF83C.doc (accessed 31 August 2005).

Brook, C. \& Oliver R. (2004) Online learning communities: exploring the impact of group size on community development, in: L. Cantoni \& C. McLoughlin (Eds) Proceedings of Ed-Media 2004, World Conference on Educational Multimedia, Hypermedia and Telecommunications (Norfolk, VA, Association for the Advancement of Computing in Education), 2518-2525.

Brownfield, G. \& Oliver, R. (2003) Factors influencing the discovery and reusability of digital resources for teaching and learning, in: G. Crisp, D. Thiele, I. Scholten, S. Barker \& J. Baron (Eds) Interact, integrate, impact: Proceedings of the 20th Annual Conference of ASCILITE (Adelaide, ASCILITE), 74-83.

Collis, B. \& Moonen, J. (2001) Flexible learning in a digital world (London, Kogan Page).

Cuban, L. (2003) Oversold and underused: computers in the classroom (Cambridge, MA, Harvard University Press).

Dennen, V. (2002) Cognitive apprenticeships in educational practice, in: D. Jonassen (Ed.) Handbook of research for educational communications and technology (2nd edn) (Hillsdale, NJ, Erlbaum).

Downes, S. (2000) Learning objects. Available online at: http://www.atl.ualberta.ca/downes/namwb/ column000523_1.htm (accessed 15 June 2002).

Flexible Learning Advisory Group (2003) Flexible learning toolboxes digital repository. Available online at: http://toolbox.flexiblelearning.net.au/search.asp (accessed 22 October 2005).

Fresen, J. (2005) Quality assurance practice in online (web-supported) learning in higher education: an exploratory study, unpublished doctoral thesis. Available online at: http:/upetd.up.ac.za/thesis/ available/etd-02172005-134301/ (accessed 12 July 2005).

Friesen, N. (2003) Three objections to learning objects and e-learning standards. Available online at: http://www.learningspaces.org/n/papers/objections.html (accessed 15 November 2004).

Garrett, R. (2004) The real story behind the failure of the UK eUniversity, Educause Quarterly, 4, 3-6. Available online at: http://www.educause.edu/ir/library/pdf/eqm0440.pdf (accessed 31 August 2005).

Hedberg, J., Wills, S., Oliver, R., Harper, B. \& Agostinho, S. (2002) Developing evaluation frameworks for assessing quality ICT-based learning in higher education, in: P. Barker \& S. Rebelsky (Eds) Proceedings of ED-MEDIA 2002 (Norfolk, VA, AACE), 736-741. 
Institute for Higher Education Policy (2000) Quality on the line: benchmarks for success in internetbased distance education. Available online at: http://www.ihep.com/Pubs/PDF/Quality.pdf (accessed 31 August 2005).

Jonassen, D. H. (2000) Toward a design theory of problem solving, Educational Technology Research and Development, 48(4), 63-85.

Kalantzis, M. \& Cope, B. (2004) Designs for learning, E-Learning, 1(1), 38-93.

Kearsley, G. (Ed.) (2005), Online learning: personal reflections of the transformation of education (Englewood Cliffs, NJ, Educational Technology Publications).

Khan, B. (Ed.) (1997) Web-based instruction (Englewood Cliffs, NJ, Educational Technology Publications).

Laurillard, D. (1993) Rethinking university teaching: a framework for the effective use of educational technology (London, Routledge).

Learning Object Metadata (2002) IEEE standard for learning object metadata, 1484, 12.1-2002, IEEE.

Learning Technology Standards Committee (2005) Learning object metadata standard. Available online at: http://ieeeltsc.org/wg12LOM/lomDescription (accessed 26 August 2005).

McKinnon, K. R., Walker, S. H. \& Davis, D. (2000) Benchmarking: a manual for Australian universities, PDF document, Higher Education Division, Department of Education, Training and Youth Affairs. Available online at: http://www.dest.gov.au/archive/highered/otherpub/ bench.pdf (accessed 31 August 2005).

McMahon, M. \& Oliver, R. (2003) Self-regulated learning, in: C. McNaught \& D. Lassner (Eds) Proceedings of Ed-Media 2003 (Norfolk, VA, AACE), 2464-2470.

Mioduser, D., Nachmias, R., Oren, A. \& Lahav, O. (1999) Web-based learning environments: current states and emerging trends, paper presented at the Ed-Media 1999, World Conference on Educational Multimedia, Hypermedia and Telecommunications, Seattle, WA.

Oliver, R. \& Brownfield, G. (2003) Factors influencing the discovery and reusability of digital resources for teaching and learning, in: G. Crisp, D. Thiele, I. Scholten, S. Barker \& J. Baron (Eds) Interact, integrate, impact: Proceedings of the $20^{\text {th }}$ Annual Conference of ASCILITE (Adelaide, ASCILITE), 74-83.

Oliver, R., Harper, B., Hedberg, J., Wills, S. \& Agostinho, S. (2002) Exploring strategies to formalise the description of learning designs, in: J. Herrington (Ed.) Proceedings of HERDSA (Joondalup, Edith Cowan University).

Oliver, R., Herrington, A., Stoney, S. \& Millar, J. (2006) Authentic teaching and learning standards that assure quality higher education, in: A. Herrington \& J. Herrington (Eds) Authentic learning environments in higher education (Hershey, Idea Group).

Oppenheimer, T. (2003) The flickering mind: the false promise of technology in the classroom and how learning can be saved (New York, Random House).

Quality Assurance Agency (2004) Code of practice for the assurance of academic quality and standards in higher education? section 2, collaborative provision and flexible and distributed learning (including e-learning). Available online at: http://www.qaa.ac.uk.com/academicinfrastructure/codeOfPractice/sections2/collabo2004.pdf (accessed 31 August 2005).

Quality Assurance Agency for Higher Education (2001) Quality assurance in higher education. Available online at: http://www.hefce.ac.uk/pubs/hefce/2001/01_45.htm (accessed 10 July 2003).

Ramsden, P. (1992) Learning to teach in higher education (London, Routledge).

Romiszowski, A. (2005) Online learning: are we on the right track(s)?, in: G. Kearsley (Ed.) Online learning: personal reflections on the transformation of education (Englewood Cliffs, NJ, Educational Technology Publications), 321-349.

Salmon, G. (2002) e-Tivities: the key to active online learning (Sterling, VA, Kogan Page).

Shepherd, C. (2000) Objects of interest. Available online at: http://www.fastrak.-consulting.co.uk/ tactix/features/objects.htm (accessed 24 June 2002). 
Sims, R., Dobbs, G. \& Hand, T. (2002) Enhancing quality in online learning: scaffolding planning and design through proactive evaluation, Distance Education, 23(2), 135-148.

Stella, A. \& Gnanam, A. (2004), Quality assurance in distance education: the challenges to be addressed, Higher Education, 47, 143-160.

University of Tasmania (2000) Quality audits and the Australian University Quality Agency. Available online at: http://www.admin.utas.edu.au/academic/acservices/meetings/talc/Appendix/6_OOD.doc (accessed July 2003). 